\title{
n-BuLi-Initiated Ring-Opening Cyclization of Cyclopropene Derivatives
}

\section{Key words}

lithium

ring-opening cyclization

cyclopropenes<smiles></smiles>

$\mathrm{R}^{1}=\mathrm{H}, \mathrm{Me}, \mathrm{Cl}, \mathrm{F}$

$\mathrm{R}^{2}=\mathrm{Ph}, \mathrm{CO}_{2} \mathrm{Me}, \mathrm{SO}_{2} \mathrm{Ph}$

$\mathrm{R}^{3}=\mathrm{CO}_{2} \mathrm{Me}, \mathrm{CO}_{2} \mathrm{Et}$

$\mathrm{n}=0,1$

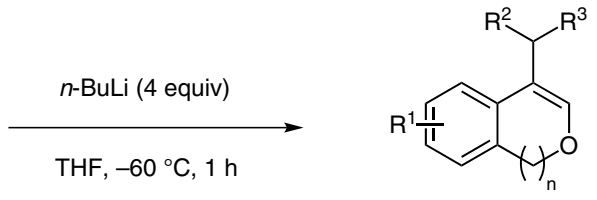

up to $72 \%$ yield

Selected examples:<smiles>CC(=O)C(C(C)=O)c1coc2ccccc12</smiles>

$72 \%$ yield<smiles>CCOC(=O)C(Sc1ccccc1)c1coc2ccc(Cl)cc12</smiles>

$59 \%$ yield<smiles>CC(=O)C(c1ccccc1)c1coc2cc(Cl)ccc12</smiles>

$64 \%$ yield<smiles>CC(=O)C(C(C)=O)C1=CCOc2ccc(Cl)cc21</smiles>

$54 \%$ yield

Proposed mechanism:

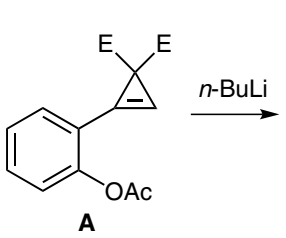<smiles>CCCCCC1CCCC1c1ccccc1OCC</smiles><smiles>Cc1oc2ccccc2c1C(F)F</smiles>

AcOD<smiles>[CH]1CC1</smiles><smiles>O=C(O)c1coc2ccccc12</smiles>

A

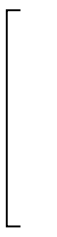<smiles>Cc1ccccc1C1CCCCC1(C(F)(F)F)C(F)(F)F</smiles>

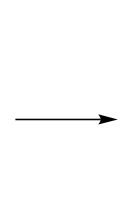<smiles>Fc1ccccc1C(F)F</smiles><smiles>[2H]c1oc2ccccc2c1C(F)(F)F</smiles>

Significance: The authors report a new access to benzocycles from cyclopropene derivatives. Treatment of 2-acetyl or 2-acetoxymethyl cyclopropenes with $n$-BuLi leads to deprotection and subsequent ring-opening cyclization to yield benzofurans and isochromenes in a one-pot procedure.

SYNFACTS Contributors: Paul Knochel, Andreas K. Steib Synfacts 2012, 8(4), 0439 Published online: 20.03.2012 Dol: 10.1055/s-0031-1290542; Reg-No.: P02512SF
Comment: Based on deuterium experiments a plausible mechanism is proposed: The reaction of A with $n$-BuLi forms $\mathbf{B}$ and the oxygen anion in $\mathbf{B}$ attacks the cyclopropene moiety to give $\mathbf{D}$. Alternatively, an excess of $n$-BuLi may further deprotonate the olefinic proton to generate dianion $\mathbf{c}$, which may also undergo ring-opening cyclization to give $\mathbf{E}$. 